\title{
CORRIGENDUM
}

\section{REVIEW OF MEXICO IN THE TIME OF CHOLERA. BY DONALD Fithian STEVENS. AlBUQUERQUE: UNIVERSITY OF NEW MEXICO PRESS, 2019. PP. 328. \$95.00 CLOTH; \$43.95 PAPER-CORRIGENDUM}

Charles F. WALKer

doi: 10.1017/tam.2020.16, Published by Cambridge University Press, 28 April 2020

$7 \mathrm{n}$ the original version of Walker 2020, a typo appeared in the name of the author of the book under review. The correct spelling is Donald Fithian Stevens.

The original review has been updated.

\section{REFERENCE}

Charles F. Walker, Review of Mexico in the Time of Cholera. By Donald Fithian Stevens. Albuquerque: University of New Mexico Press, 2019. Pp. 328. \$95.00 cloth; $\$ 43.95$ paper. The Americas 77:2 (2020), 320-321. 